\title{
The analysis ability of technological content knowledge (TCK) of biology education's students in Universitas Ahmad Dahlan in preparation of learning plan
}

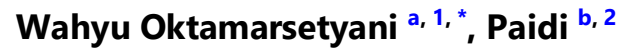 \\ a Post-graduate of Biology Education, Yogyakarta State University, Indonesia

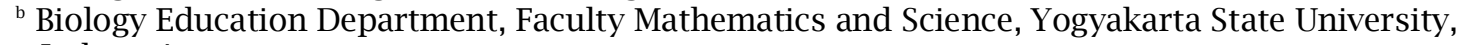 \\ Indonesia \\ ${ }^{1}$ wahyuoktamarsetyani@gmail.com *, ${ }^{2}$ paidi@uny.ac.id \\ * Corresponding author
}

\begin{tabular}{ll}
\hline \multicolumn{2}{l}{ ARTICLE INFO } \\
\hline \multicolumn{2}{l}{ Article history } \\
Received $\quad$ January 152019 \\
Revised & September 92019 \\
Accepted & October 22019 \\
\hline Keyword: & \\
Technological content knowledge \\
Biology education student \\
Lesson plan
\end{tabular}

\begin{abstract}
Technological Content Knowledge is the student's (prospective biology teachers) knowledge in determining certain technologies that will be used in the learning process. This knowledge is important for prospective teachers because it can help students in understanding the material that has been conveyed. The objective of this study is to examine the ability of Technological Content Knowledge (TCK) of biology education students in preparing learning plans. The study is a quantitative descriptive research by using survey method. Participants of this study are all biology education students a total of 120 students in the Faculty of teacher training and education in Universitas Ahmad Dahlan 6th semester academic year 2017/2018. Data collection techniques use a non-test instrument of the learning plan document observation sheet and the instrument on the written tests about technological knowledge and biological content. The data obtained is statistically analyzed in a descriptive form intended to figure out the capabilities of the TCK's student. In order to the acquired results can be trusted and reduce subjectivity, a compatibility test is conducted between panelists. The results showed that: (1) biology education students have TCK ability which is less than reviewed for learning plan, (2) biology education students have TCK skills worth in terms of written test result about TCK knowledge.
\end{abstract}

\section{Introduction}

To prepare teachers in the 21 st century, prospective teachers need to be equipped with the use of information technology and communication in their studies. Göktaș, Yildirim and Yildirim (2008) argue that many education courses in Asia are redesigning curriculum in order to prepare prospective professional teachers in the future. In keeping with the Presidential Regulation No. 8 of 2012 on the Indonesian National Qualification Framework (KKNI) and Law No. 12 of 2012 regarding graduates of all colleges to have an equal ability to formulate in the Indonesian National Qualification Framework (KKNI) qualification level. Indonesian National 
Qualification Framework's (KKNI) formulation includes the ability to mastery graduates in the field of expertise, utilizing science, technology in solving problems, be able to adapt to the situation faced, and be able to master the concept theoretically well Specifically in certain areas of knowledge in depth. The regulation has been specially arranged by the ministry of research technology and higher education (Kemenristekdikti) number 55 year 2017, states that the achievement's formulation of undergraduate learning includes attitudes, knowledge, and personality. To master the achievement of learning can be facilitated with the mastery of three basic knowledge, there are content knowledge, pedagogy, and technology that is part of the achievement of learning to prepare the prospective teachers in the future. As the era grew today Koehler and Mishra (2005) developed a model called Technological Pedagogical Content Knowledge (TPACK) developed based on Shulman's Pedagogical Content Knowledge (PCK) skeleton Model (1986). Koehler and Mishra (Nordin, Davis, \& Ariffin, 2013) developed a TPACK model acquired from the addition of a technology in Pedagogical Content Knowledge (PCK) in order to became a TPACK. TPACK is a cutting point or meeting of the knowledge of content, technology, and pedagogy as well as the depiction of integration of technology related to the environment of teaching-learning process (Lux, Bangert, \& Whittier, 2011), the integrating can be used to support the teaching process in class (Niess et al., 2009). The following is the TPACK scheme that can be seen in Figure 1.

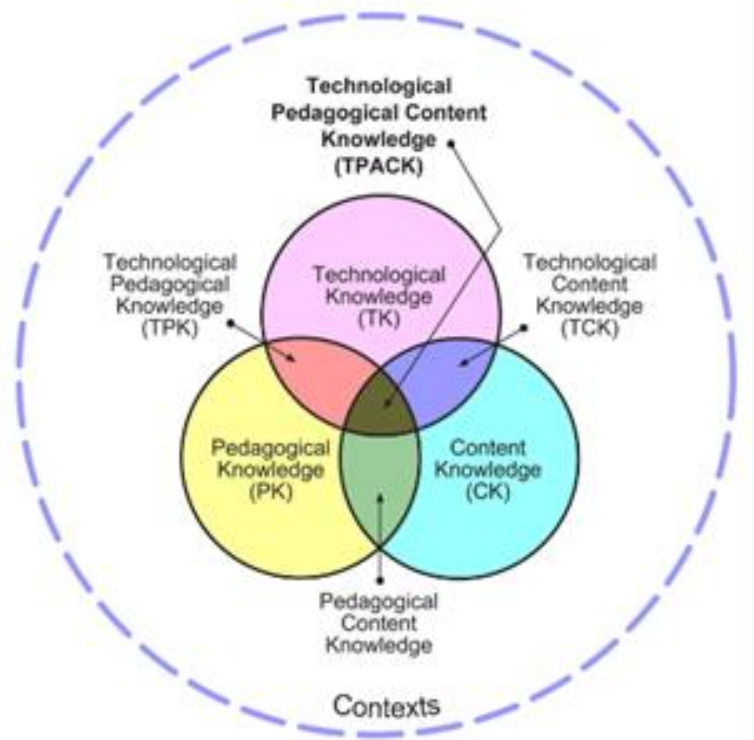

Figure 1. TPACK framework (Koehler \& Mishra, 2009)
TPACK framework has 7 components, there are: (1) Content Knowledge (CK), (2) Pedagogical Knowledge (PK), Technological Knowledge (TK), Pedagogical Content Knowledge (PCK), (5) Technological Content Knowledge (TCK), (6) Technological Pedagogical Knowledge (TPK), and (7) Technological Pedagogical Content Knowledge (TPACK) is an integration of three knowledge domains (technology, pedagogic, and content) that facilitate the learning process of learners.

The framework means that the addition of technology is able to change the knowledge of a teacher or prospective teacher. One component of TPACK is the integration between technology and content (TCK). TCK as the basic ability for teachers and prospective teachers to face challenges in the 21 st century. Some peculiarities that reflect 21 st-century learning is to optimize ICT in support of the learning process in order to the objectives can be achieved. ICT can help develop learners' thinking skills according to their development level. TCK helps teachers describe the content of certain materials with technology that can be integrated in learning. For example, in learning there are some abstract biological material in order to the object is required to be concrete and can be captured by the senses, therefore it is expected that ICT as part of technology knowledge can be used to help teachers and prospective teachers simulate computer-assisted teaching materials. So the teaching material can be conveyed concrete and empirically. Koehler and Mishra (2005) argue that TCK is a knowledge of the reciprocal relationship between technology and content affecting one another. Whether an educator or prospective educator needs to understand the specifics of the technology that is the greatest suited for the learning of certain materials (Sahin, 2011).

Teaching and learning activities are not separated from learning equipment. According to Sholihah, Yuliati and Wartono (2016), A teacher must have the ability to compose a learning device, because of how a teacher teaches is reflected in the learning equipment it is in. One such learning equipment is a plan of learning that has an important role, therefore the prospective teachers need to be equipped with the ability to develop a learning plan including prospective biological teachers in the Biology Education Study Program. Then the Program will approve the prospective 
biology teachers. A prospective biological teacher must have the ability to develop the learning process through a learning plan. The Learning Plan has an important role before the implementation of learning with the goal that learning is systematic and effective. The Learning Plan certainly has a component that should be listed for the expected complications achievable. According to the regulation of the minister of education and culture (Permendikbud) No. 22 of 2016 on the standard of basic and secondary education process mentions aspects of the Learning Plan include (1) The identity of the subjects; (2) Formulation of core competencies; (3) Formulation of indicators; (4) The formulation of learning objectives; (5) The formulation of teaching materials; (6) Selection of learning media; (7) Learning methods/approaches/models; (8) Learning measures; (9) Learning assessment design; and (10) evaluation design/followup assessment results. If some aspects can be fulfilled, the teaching and learning activities can be well-run and the competencies that are expected to be achieved.

Nowadays, a description of the ability of teachers or prospective teachers to develop learning plans is not fully compliant, it is supported by the results of research conducted by Ernawati and Safitri (2018) that there are some difficulties experienced by the teacher of science subjects (Kima, physics, and biology) in designing learning plans which are not optimal in obtaining training in the preparation of learning plans, can not use computer-based devices and the internet optimal, and difficulty in selecting a learning approach/ method/ strategy. This can happen due to the weakness of knowledge and technology developments.

However, the ability to compose a good learning plan is less sufficient. To create effective teaching and learning activities, mastery some of the things is needed which is very mastering the concept of material content and at least know the current growing technology, information, and communication (ICT) So the difficulty in crafting learning plans can be diminished. Fundamental to the effective learning process is that if prospective teachers can integrate between material content with the appropriate technology (Göktaș et al., 2008). It is important to mastery knowledge regarding the content of biological material and technological knowledge. TCK's knowledge shows that technology and material content influence each other and support one another. According to Sahin (2011), Teachers need to understand specifically the most suitable/appropriate technology to be applied in biological learning (Sahin, 2011). That is, teachers and prospective teachers should have knowledge of the subject matter or knowledge in the use of appropriate technology. It can be outlined in writing in the Learning Plan itself in order to the learning process can go well and the competency set can be achieved. For example, to know the idea of DNA is need visualization with the help of technologies such as video software, animated drawings or simulation, and others.

Knowledge is important for prospective biology teachers because in determining the technology to be used, prospective biology teachers must understand the biology material itself, in addition to that the mastery of knowledge is used as a basis in drafting a Learning Plan. According to Harris and Hofer (2011), The preparation of the Learning Plan reflects the ability of TPACK owned by prospective biological teachers. It is known that TPACK has 7 components of knowledge one of which is TCK, if the ability of TPACK is great, so TCK will be great too.

Given the importance of these skills for prospective biology teachers and so far there is no information about mastering the skills of TCK's prospective biology teacher at Universitas Ahmad Dahlan, this research needs to be done.

\section{Method}

This research is a quantitative descriptive study by using the survey method. Participants in this study are all students of Biology education program Faculty of teacher training and education Universitas Ahmad Dahlan) 6th-semester academic year 2017/2018. The sampling technique was made by all participants of 120 students using a census.

The data collection techniques are using non-test instruments and non-tests. Non-test instruments include an observation sheet for a learning plan that contains aspects as an assessment indicator. The judging aspects and indicators are shown in Table 1. The objective of the instrument test is to understand the extent of the knowledge of 
the concepts and theories of biological and technological content as the basis for preparing a learning plan. Test instrument in the form of a written test of knowledge technology consisting of 5 grains problem while the knowledge test content biology histology and animal embryologist, consisting of 25 items, the test is given to students at the end of learning. A grid of knowledge test technologies includes knowledge of the principles and techniques of the use of information and communication technology (ICT) in biological learning, whereas the grid of knowledge tests on biological content include structural material and Functions of four basic animal tissues (epithelial tissue, connective tissue, muscle tissue, and neural tissues), reproductive system, fertilization and development of human embryo as well as embryology comparison of various vertebrates groups. Before the instrument is used in advance the validity and reliability of the instrument by members/experts that include the validity of the contents and the construct, the results are valid with several revisions according to the recommendations, while the reliability of the instrument test problem is done with the principle norm Reference test (NRT) which the goal is to know the level of TCK student capability in the group. As a result, the test item has a moderate (medium) difficulty index which means that the test item is not too tough or too easy.

The Data that has been obtained is analyzed in a descriptive statistical meaning describing the phenomena that occur directly. By using the assessment quoted from the Directorate of High School Development (Direktorat Pembinaan SMA) (2010) in order for can describe the objective of the implementation of learning activities is to know about the ability of TCK biological education students.

Table 1. The aspect of the learning plan

\begin{tabular}{|c|c|}
\hline Aspect & Indicator \\
\hline $\begin{array}{l}\text { Teaching materials } \\
\text { Selection }\end{array}$ & $\begin{array}{l}\text { Conformity of teaching materials with the basic competencies (KD) indicator and } \\
\text { learning objectives } \\
\text { The suitability of teaching materials with basic competencies (KD) indicator and } \\
\text { learner characteristics. } \\
\text { The breakdown of teaching material. } \\
\text { ICT supports integrating with teaching materials } \\
\text { It contains material content that supports development in activities and projects. }\end{array}$ \\
\hline $\begin{array}{l}\text { Learning Media } \\
\text { Selection }\end{array}$ & $\begin{array}{l}\text { Suitability of media selection with learning objectives, teaching material } \\
\text { characteristics, student characteristics, and ICT. }\end{array}$ \\
\hline $\begin{array}{l}\text { Method selection/ } \\
\text { Approach/Learning } \\
\text { model }\end{array}$ & $\begin{array}{l}\text { Suitability of learning methods with learning objectives, teaching materials, } \\
\text { approaches, material characteristics, and learners ' characteristics. } \\
\text { The suitability of learning approaches with learning objectives, teaching materials, } \\
\text { approaches, material characteristics, and learner's characteristics. } \\
\text { The suitability of learning models with learning objectives, teaching materials, } \\
\text { approaches, material characteristics, and learner's characteristics. }\end{array}$ \\
\hline Learning steps & $\begin{array}{l}\text { The implementation of learning activities includes an opening, core, and closing } \\
\text { activities that are implemented on the material being taught. }\end{array}$ \\
\hline
\end{tabular}

\section{Results and Discussion}

A learning plan is one of the learning equipment in which there is learning activities plan as a teacher's guide in teaching class. There are several aspects of the learning plan including the learning objectives, material taught, learning methods, learning media, learning resources, and assessment of learning outcomes. In this study, to understand the ability of students' TCK the selection of aspect teaching materials, the selection of instructional media, the selection of methods/approaches/learning models and learning steps are limited. The following
Table 2 is a recapitulation result of TCK's student ability level in preparing learning plans.

Table 2 shows that TCK 's ability level of the biology education students in preparing learning plans, according to panelist $A$ the average value of 32.66 and panelist B of 33.53 it means that the criteria is less with the scores range of $62.5 \leq \mathrm{M}<$ 81.25 according to Directorate of High School Development (2010). To reduce subjectivity among panelists then tested compatibility. By using canonical test Krippendorf (2004) obtained the suitability value equal to $1(\alpha=1)$ it means that all the data obtained has the perfect match. 
Table 2.TCK's level of ability in developing learning plans

\begin{tabular}{lcccc}
\hline \multirow{2}{*}{ Lesson Plan's Aspect } & \multicolumn{2}{c}{ Panelist } & Compatibility value test & Exp \\
\cline { 2 - 5 } & Panelist A & Panelist B & 1,00 & Less \\
\hline Teaching Materials Selection & 32,40 & 35,90 & 1,00 & Less \\
Learning Media Selection & 30,00 & 30,00 & 1,00 & Less \\
Selection of method / approach & 37,00 & 37,00 & 1,00 & Less \\
/Learning models & 31,25 & 31,25 & 1,00 & Less \\
Steps of Learning & 32,66 & 33,53 &
\end{tabular}

Explanation: $81.25 \leq \mathrm{M} \geq 100$ = excellent; $62.5 \leq \mathrm{M}<81.25$ = good; $43.75 \leq \mathrm{M}<62.5$ = sufficient; $25 \leq \mathrm{M}<43.75=$ less (Directorate of High School Development, 2010)

Based on the results of the research in Table 2, it is known that in the aspect of selection instructional media and teaching materials included in the category of "inadequate" it can be said that the average students TCK capability is still less good, it might because of the students have not been able to arrested the technology used with the content biology in compiled learning plans. Technological knowledge is focused on the use of technology, communication and information (ICT) such as the use of power-point media, video, animated images, e-learning, and others. The results of the learning plan's observation show that some student already understands and uses a variety of technologies to help the learning process both conventional and modern. But students have not been able to determine the appropriate learning media for the teaching material in order to the ability of TCK has not been well-reflected.In certain biology material that is supposed to display visualizations such as videos, but students only use pictures. In this era technology has grown rapidly, it is expected that students as the prospective biology teachers can be integrated teaching materials with ICT that are adapted to the learning goals in order to the expected competencies that can be achieved. Hopefully, that utilizing ICT will make it easier for teachers to convey their teaching material and for students it will be easier to arrested and understand the teaching material that has been conveyed. This encourages students to mastering technological knowledge and content where this knowledge invites to know the use of certain technologies that can help understand the concept of a particular material and content. Although the use of technology is important, but there are components that must be considered in selection of learning media include the media must be adapted to the condition of the situation right now and the student's condition (Reiser \& Dick, 1996).
Based on the learning plan document observations, the selection of methods/ approaches and learning models is categorized in the "inadequate" category. There are several methods, approaches, and learning models selection by students which inconsistent with the material being taught. The use of appropriate learning methods, approaches, and models in the teaching and learning process has a role to assist students in implementing the learning media in order to the TCK ability of students will also be reflected well. If the methods, approaches and learning models are appropriate then the teaching material will be conveyed properly. In addition, the criteria in the selection of methods, approaches and learning models have not been completely fulfilled. The selection of the term approaches, models, and methods are often poorly understood, even when already a teacher (Zubaidah, 2010). The goal of the accuracy of the method selection, approaches and learning models used by teacher is to create a learning atmosphere and learning process in order for students to achieve basic competencies and indicators that have been set (Lestari, 2013).

The learning steps in the learning plan include opening activities, core activities, and closing activities. Based on observations of the learning plan categorize into "inadequate" category. In this opening activity, some students write apperception just by asking students what material will be studied without showing a detailed description of the material. In general, apperception activities are conveyed verbally by students in front of the class, when in fact, these apperception activities can utilize the media to convey it, such as using videos, pictures, or other media that can optimize apperception. However, in the fact the students who use the media to convey apperceptions are less; if it can be done it will be easier for students to understand the material to be learned that day. These activities should be done well 
before entering into the core activities because the opening activity is the beginning of the whole learning process.

Core activities are the main activities in learning. Observation results show that the ability of students in the core activities is also still categorized into "inadequate ", it might because there are some students who have not been appropriate in writing the steps in applying the learning model. Some student also does not describe in detail about the use of instructional media such as video play or uses images to be observed, in order to this activity the TCK ability of students has not been reflected.

Closing lesson activity is an activity that purpose to conclude the core activities. Based on observations in the learning plan is categorize into "inadequate", it might because the main components in the closing lesson have not been included. According to Barnawi and Arifin (2016) state that the main component of closing the lesson is consists of reviewing, evaluating assignments and providing follow-up. In this follow-up, students as prospective teachers can assign their students to look for reference material through the internet with the purpose of broader student knowledge.

In order for the learning process to run well, a biology teacher must have skills in developing learning scenarios, but this will not be optimal without the ability to mastering the knowledge of biological content to be taught for students. With the provision of good knowledge, biology teachers are able to follow the latest developments related to the field of biology. In keeping with the opinion of Herning, Koehler, and Mishra (2014) argue that not only knowledge of biological content, but teachers must have the ability to follow the development of new information technology, it can be achieved if the teacher has good technological knowledge, technological knowledge leads to knowledge of conventional technology and new technology that can be integrated with subject matter. According to Regulation of the Ministry of Research and Technology No. 55 of 2017 concerning learning outcomes for graduates of undergraduate programs is mastering the competence of scientific fields or expertise. Which is includes mastering the knowledge of biological content, pedagogical knowledge and technological knowledge. To understand the mastery of this knowledge can be measured using written tests. The results obtained from the written test can be seen in Table 3.

Table 3.TCK ability levels based on written knowledge test results

\begin{tabular}{lcl}
\hline \multicolumn{1}{c}{$\begin{array}{c}\text { Lesson Plan's } \\
\text { Aspect }\end{array}$} & $\begin{array}{c}\text { Compatibility } \\
\text { value test }\end{array}$ & Exp \\
\hline $\begin{array}{l}\text { Biology / Content } \\
\text { Knowledge (CK) }\end{array}$ & 47.67 & Sufficient \\
$\begin{array}{l}\text { Technological } \\
\text { Knowledge (TK) } \\
\text { Technological }\end{array}$ & 53.33 & Good \\
$\begin{array}{l}\text { Knowledge and } \\
\text { Content (TCK) }\end{array}$ & 53.33 & Good \\
Averaging & 51.44 & Sufficient \\
\hline
\end{tabular}

Explanation:

$81.25 \leq \mathrm{M} \geq 100=$ Excellent; $62.5 \leq \mathrm{M}<81.25=$ Good

$43.75 \leq \mathrm{M}<62.5=$ Sufficient; $25 \leq \mathrm{M}<43.75=$ Less

(Directorate of High School Development, 2010)

This written test is carried out with the objective of knowing the extent of knowledge about biological content and technological knowledge possessed by students which is used as a basis in preparing learning plans. Based on the results obtained from the written test, it is known that the students having the ability to know biological content are in the "adequate" category the acquisitions of a number for biological knowledge of 47.67 which is in the range of $25 \leq \mathrm{M}<50$. Judging from these results indicate that the mastery of biological material students is good enough, but this knowledge needs to be increased again as a provision of teaching in the future. The ability to mastering and provide new information development about the material taught to students is an ability that must be possessed by a teacher. Without mastery of the material it will allow a misconception about the content of the material to be taught. Knowledge about content is very important for teachers and prospective teachers (Koehler \& Mishra, 2009). Content knowledge contains knowledge about concepts, theories, ideas, frameworks, knowledge of proof, and practices and approaches to develop that knowledge (Sahin, 2011).

Technology knowledge of biology education students is in the "good" category with a score 53.33. Technology knowledge is learning about information technology, hardware, software and other devices (Can, Erokten, \& Bahtiyar, 2017). Technological knowledge leads to the knowledge of teachers and prospective teachers about conventional and new technologies that can 
be integrated with the curriculum (material content) (Herning et al., 2014). Technological knowledge also includes the ability to adapt and learn new technologies. The existence of this ability needs to be had given the development and technological changes continuously occur (Rosyid, 2016).

Technology and content knowledge is knowledge about the reciprocal relationship between technology and content (Koehler \& Mishra, 2005). Technology and content knowledge is an understanding of how technology and content knowledge influence one another. Based on the research results listed in Table 3, it is known that the ability of students to master technological knowledge and content is 53.33 which are in the "good" category. These results are a proof that students have the knowledge to combine/ integrate technological knowledge and content well.

\section{Conclusion}

Based on the research result and discussion, it is concluded that the description of biology education students TCK's level of ability in preparing learning plans falls into the "inadequate" category. Overall there are weaknesses that still found in the learning plan. Weaknesses are generally found that prospective teachers are not optimal in utilizing technology (ICT) to assist in teaching and there are still mismatches in choosing teaching materials, learning media and methods/ approaches/ learning strategies with technology written in the learning plan. The value of technology and content knowledge test results is quite good although not yet maximal in its application. With these results can certainly be a picture of how the ability of TCK students in preparing learning plans. The recommended suggestion is the results of this study can be used as information material as a basis for consideration in an effort to improve the ability of biology education students in preparing learning plans.

\section{References}

Barnawi, \& Arifin, M. (2016). Microteaching: Teori \& praktik pengajaran yang efektif \& kreatif. Yogyakarta: ArRuzz Media.

Can, B., Erokten, S., \& Bahtiyar, A. (2017). An investigation of pre-service science teachers' Technological Pedagogical content knowledge. European Journal of Educational Research, 6(1), 51-57. https://doi.org/ 10.12973/eu-jer.6.1.51

Direktorat Pembinaan SMA. Juknis penyusunan perangkat penilaian afektif di SMA. , (2010).

Ernawati, E., \& Safitri, R. (2018). Analisis kesulitan guru dalam merancang rencana pelaksanaan pembelajaran mata pelajaran fisika berdasarkan kurikulum 2013 di kota Banda Aceh. Jurnal Pendidikan Sains Indonesia, 5(2), 50-58. https://doi.org/ 10.24815/jpsi.v5i2.9817

Göktaș, Y., Yildirim, Z., \& Yildirim, S. (2008). The key for ict integration in k-12 education: Teachers' perceptions and usage. Hacettepe University Journal of Education, 34, 127-139. Retrieved from https://dergipark. org.tr/en/pub/hunefd/issue/7802/ 102254

Harris, J. B., \& Hofer, M. J. (2011). Technological pedagogical content knowledge (TPACK) in action: A descriptive study of secondary teachers' curriculum-based, technology-related instructional planning. Journal of Research on Technology in Education, 43(3), 211$229 . \quad$ https://doi.org/10.1080/ 15391523.2011.10782570

Herning, M. C., Koehler, M. J., \& Mishra, P. (2014). Handbook of technological pedagogical content knowledge (TPCK) for educators. New York: Routledge.

Koehler, M. J., \& Mishra, P. (2005). What happens when teachers design educational technology? The development of technological pedagogical content knowledge. Journal of Educational Computing Research, 32(2), 131-152. https:// doi.org/10.2190/0EW7-01WB-BKHLQDYV

Koehler, M. J., \& Mishra, P. (2009). What is technological pedagogical content knowledge. Contemporary Issues in Technology and Teacher Education, $9(1), \quad 60-70 . \quad$ Retrieved from https://www.learntechlib.org/prima $\mathrm{ry} / \mathrm{p} / 29544$ /

Krippendorf, K. (2004). Content analysis an introduction to its methodology 
(2nd ed.). London: SAGE Publications.

Lestari, I. (2013). Pengembangan bahan ajar berbasis kompetensi. Padang: Akademia Permata.

Lux, N. J., Bangert, A. W., \& Whittier, D. B. (2011). The development of an instrument to assess preservice teacher's technological pedagogical content knowledge. Journal of Educational Computing Research, 45(4), 415-431. https://doi.org/ 10.2190/EC.45.4.c

Niess, M. L., Ronau, R. N., Shafer, K. G., Driskell, S. O., Harper, S. R., Johnston, C., ... Kersaint, G. (2009). Mathematics teacher TPACK standards and development model. Contemporary Issues in Technology and Teacher Education, 9(1), 4-24. Retrieved from https://www. learntechlib.org/p/29448/

Nordin, H., Davis, N., \& Ariffin, T. F. T. (2013). A case study of secondary pre-service teachers' technological pedagogical and content knowledge mastery level. Procedia - Social and Behavioral Sciences, 103, 1-9. https://doi.org/10.1016/j.sbspro.20 13.10 .300

Reiser, R. A., \& Dick, W. (1996). Instructional planning: A guide for teachers. Boston: Allyn and Bacon.

Rosyid, A. (2016). Technological Pedagogical Content Knowledge: Sebuah kerangka pengetahuan bagi guru Indonesia di era MEA. Prosiding
Seminar Nasional Inovasi Pendidikan. Surakarta: Universitas Sebelas Maret.

Sahin, I. (2011). Development of survey of technological pedagogical and content knowledge (TPACK). The Turkish Online Journal of Educational Technology, 10(1), 97105. Retrieved from http://www. tojet.net/articles/v10i1/10110.pdf

Sholihah, M. 'atus, Yuliati, L., \& Wartono, W. (2016). Peranan TPACK terhadap kemampuan menyusun perangkat pembelajaran calon guru fisika dalam pembelajaran post-pack. Jurnal Pendidikan: Teori, Penelitian, Dan Pengembangan, 1(2), 144-153. Retrieved from http://journal.um. ac.id/index.php/jptpp/article/view/ 6115

Zubaidah, S. (2010). Berpikir kritis: Kemampuan berpikir tingkat tinggi yang dapat dikembangkan melalui pembelajaran sains. Seminar Nasional Sains 2010 Dengan Tema "Optimalisasi Sains Untuk Memberdayakan Manusia," 1-14. Retrieved from https://www. researchgate.net/profile/Siti_Zubai dah5/publication/318040409_Berpi kir_Kritis_Kemampuan_Berpikir_Tin gkat_Tinggi_yang_Dapat_Dikemban gkan_melalui_Pembelajaran_Sains/li nks/59564c650f7e9b591cda994b/B erpikir-Kritis-Kemampuan-BerpikirTingkat-Tinggi 